\title{
1.2C-1Si-17Cr-2.5Mo-0.8V 工具鋼の経年ひずみ
}

\author{
渡辺 義雄 ${ }^{*} \cdot$ 杉本 公一 ${ }^{* 2} \cdot$ 三輪 一平 ${ }^{* 3} \cdot$ 西沢 誠夫*
}

Distortion in Service of a $1.2 \mathrm{C}-1 \mathrm{Si}-17 \mathrm{Cr}-2.5 \mathrm{Mo}-0.8 \mathrm{~V}$ Tool Steel

Yoshio Watanabe, Koh-ichi Sugimoto, Ippei Miwa and Masao NishizaWa

Synopsis : The effects of tempering temperature on distortion in service of a $1.2 \mathrm{C}-1 \mathrm{Si}-17 \mathrm{Cr}-2.5 \mathrm{Mo}-0.8 \mathrm{~V}$, mass $\%$, tool steel which was developed for precision molding die of semi-conductors such as LSI were investigated. When tempered at $490^{\circ} \mathrm{C}$ after quenched from $1125^{\circ} \mathrm{C}$ followed by subzero treating, the steel possessed a very small distortion in service less than $1 \times 10^{-5}$ under cooling-heating cyclic test, in accompany with a significant hardness above $62 \mathrm{HRC}$. The small distortion in service was associated with an increase in retained austenite stability against the martensite transformation which was evaluated by lattice parameter of the retained austenite and its increment on tempering. It was expected that the stabilization of the retained austenite was resulted from dissolution of $\mathrm{M}_{3} \mathrm{C}$ carbides and suppression of $\mathrm{M}_{23} \mathrm{C}_{6}$ alloy carbide precipitation.

Key words: tool steel; retained austenite; distortion; secondary hardening; heat treatment; lattice parameter; retained austenite stability; carbide precipitation; precision die.

\section{1. 緒言}

最近の半導体素子パッケージング用の工具鋼製超精密 モールド金型は焼入れ・焼戻し处理後に放電加工処理，プ ラズマ表面硬化処理などの高温处理が施されることが多く なってきた1,2)。このため, このような金型材料には，高 温焼戻し状態で，高い硬さ（62 HRC以上），優れた耐食性

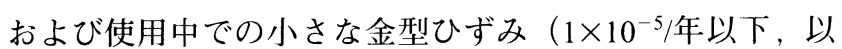
降では，焼入れ時の熱処理ひずみまたは焼きひずみと区別 するため，経年ひずみと称する）が求められている。

現在市販されている熱間工具鋼および冷間工具鋼に， $500^{\circ} \mathrm{C}$ 前後の高温焼戻しを施して $62 \mathrm{HRC}$ 以上の硬さを得 ることは難しい。このため, 松田ら ${ }^{3)}$ はSKD11鋼をべース として高温焼戻し状態で大きな2次硬化を生ずる $1 \mathrm{C}-1 \mathrm{Si}-$ $8 \mathrm{Cr}-2 \mathrm{Mo}$ 鋼を開発した。この鋼は $500^{\circ} \mathrm{C} て ゙ 2$ 時間の焼戻し によって $63.5 \mathrm{HRC} の$ 硬さが得られるが， Cr添加量が低い ため本質的に耐食性がそしく，上述の超精密金型に用いる ことは難しい。そこで著者らは，優れた耐食性と小さな経 年ひずみを有する SUS440C鋼をべースに, 2次硬化元素で ある Mo と Vを添加した $1.2 \mathrm{C}-1 \mathrm{Si}-17 \mathrm{Cr}-2.5 \mathrm{Mo}-0.8 \mathrm{~V}$ 鋼を開 発した ${ }^{4)}$ 。しかし，この開発鋼の経年ひずみ抢よび硬さに 及ぼす焼戻し温度の影響については現在のところ明らかで ない。

一般に, $\mathrm{Fe}-\mathrm{C}-\mathrm{Cr}$ 系工具鋼に焼入れ後サブゼロ処理を施
したときの組織は粗大な一次炭化物，マルテンサイト $\left(\alpha^{\prime}\right)$ 母相, 残留オーステナイト $(\gamma)$ からなる。2次硬化温度域で 焼戻しを施したとき， $\alpha^{\prime}$ 母相では微細な $\mathrm{M}_{7} \mathrm{C}_{3}, \mathrm{M}_{23} \mathrm{C}_{6}$ 合 金炭化物の両方またはどちらかが析出する ${ }^{5,6)}$ 。一方，残 留 $\gamma$ 内では残留 $\gamma$ の不安定化とそれによる冷却中の $\alpha^{\prime}$ 変態 が生じ，これらが2次硬化を生じさせる主な原因であると 考えられている7)。このような $\mathrm{Fe}-\mathrm{C}-\mathrm{Cr}$ 鋼では，2次硬化 領域における硬さの極大值は残留 $\gamma$ の分解開始温度付近で

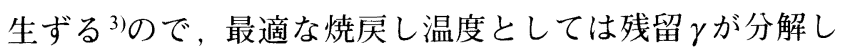
ない上限温度が採用される。この場合, 残留 $\gamma$ の安定性は 焼戻し温度によって変化し，使用中の金型寸法を変化させ ることが予想されるが，このような観点から残留 $\gamma$ 特性を 調査した研究は現在までなされていない。

そこで本研究では，まず， $1.2 \mathrm{C}-1 \mathrm{Si}-17 \mathrm{Cr}-2.5 \mathrm{Mo}-0.8 \mathrm{~V}$ 鋼 の経年ひずみと硬さに及ぼす焼戻し温度の影響を調査し

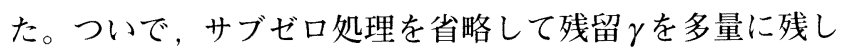
た同じ鋼を用いて，残留 $\gamma$ 特性（格子定数と体積率）と炭 化物の析出挙動を詳細に調査し, これらより経年ひずみの 焼戻し温度依存性を検討した。

\section{2. 実験方法}

供試鋼には真空溶解後，ESR 处理，熱間鍛造，熱間圧延， 球状化焼鈍し処理を順次施した板厚 $20 \mathrm{~mm}$ の $1.2 \mathrm{C}-1 \mathrm{Si}-$ $17 \mathrm{Cr}-2.5 \mathrm{Mo}-0.8 \mathrm{~V}$ 鋼（以下では $\mathrm{A}$ 鋼と称す）を用いた。比

平成 12 年 6 月 1 日受付 平成 12 年 8 月 3 日受理 (Received on June 1, 2000; Accepted on Aug. 3, 2000)

* アピックヤマダ (株) 事業支援本部 (Manufacturing Engineering Department, APIC Yamada Co., Ltd., 90 Kamitokuma Toguramachi Hanishina-gun Nagano-ken 389-0898)

* 2 信州大学工学部 (Faculty of Engineering, Shinshu University)

*3 信州大学工学部大学院生 (Graduate Student, Shinshu University) 
Table 1. Chemical composition of steels A, B and C used. (mass\%)

\begin{tabular}{c|c|c|c|c|c|c|c|c}
\hline Stee & $\mathrm{C}$ & $\mathrm{Si}$ & $\mathrm{Mn}$ & $\mathrm{P}$ & $\mathrm{S}$ & $\mathrm{Cr}$ & Mo & $\mathrm{V}$ \\
\hline $\mathrm{A}$ & 1.20 & 0.99 & 0.59 & 0.010 & 0.001 & 16.81 & 2.51 & 0.77 \\
$\mathrm{~B}$ & 1.43 & 0.21 & 0.43 & 0.019 & 0.002 & 11.69 & 0.84 & 0.24 \\
$\mathrm{C}$ & 1.31 & 0.25 & 0.33 & 0.018 & 0.008 & 18.20 & 4.02 & 1.05 \\
\hline
\end{tabular}

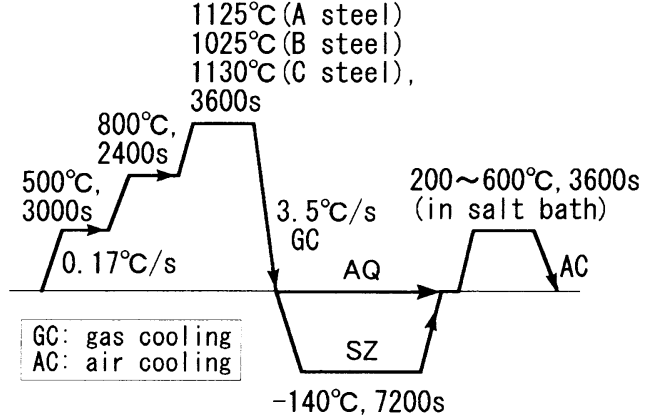

Fig. 1. Heat treatment diagram of steels.

較材として，市販のSKD11 相当鋼（以下では，B鋼と称す） を用いた。また，一部の実験には，粉末焼結法によって製 造された $1.31 \mathrm{C}-0.25 \mathrm{Si}-18 \mathrm{Cr}-4 \mathrm{Mo}-1 \mathrm{~V}$ 鋼（以下では，C鋼 と称す）も用いた。これらの鋼の化学組成を Table 1 に示 于。

これらの鋼から厚さ $15 \mathrm{~mm}$, 幅 $20 \mathrm{~mm}$, 長さ $110 \mathrm{~mm}$ の 蓺処理ひずみおよび経年ひずみ測定用試験片を作製後, $1125^{\circ} \mathrm{C}$ (A 鋼)， $1025^{\circ} \mathrm{C}$ (B鋼) または $1130^{\circ} \mathrm{C}(\mathrm{C}$ 鋼 $)$ で $3600 \mathrm{~s}$ 保持後加圧ガス冷却し，直ちに $-140^{\circ} \mathrm{C} て ゙ 7200 \mathrm{~s}$ の サブゼロ処理を施した。さらに，塩浴中において200〜 $600^{\circ} \mathrm{C}$ で $3600 \mathrm{~s}$ の焼戻しを施した(Fig. 1)。ただし, 残留 $\gamma$ の格子定数変化および残留 $\gamma$ 内の炭化物析出挙動の調査を 容易にするため，焼入れ後のサブゼロ処理を省略した試験 片も作製した。以下では，サブゼロ処理を施したものを “SZ材”，省略したものを“AQ材”と称する。

一般に，サブゼロ処理と焼戻しを交互に繰返すことに よって, 残留 $\gamma$ の分解が加速される7》。そこで本研究では, 恒温槽を用いた冷却・加熱サイクル試験(Fig. 2)によって経 年ひずみを評価した。ここで, 繰り返し数は最大 5 回とし た。また, サイクル試験の低温側は残留 $\gamma$ の変態がほぼ停 止する温度 ${ }^{\dagger}$ り少し低い温度 $\left(-140^{\circ} \mathrm{C}\right)$, 高温側は金型使 用温度 $\left(180^{\circ} \mathrm{C}\right)$ より少し高い温度 $\left(200^{\circ} \mathrm{C}\right)$ とした。

経年ひずみは，冷却・加熱サイクル試験を行った試験片 の長さ変化量 $\Delta l$ を元の長さ $l_{0}(=110 \mathrm{~mm})$ で除した長手方向 ひずみ $\left(\varepsilon_{\mathrm{S}}=\Delta l / l_{0}\right)$ によって求めた。本研究では, 焼入れ後, サブゼロ処理後，および焼戻し処理後のそれぞれの寸法変 化（熱処理ひずみ $\varepsilon_{H}$ ）も同様な方法で求めた。

残留 $\gamma$ の体積率はMo-K $\alpha$ 線によって測定した $\alpha$ 相およ

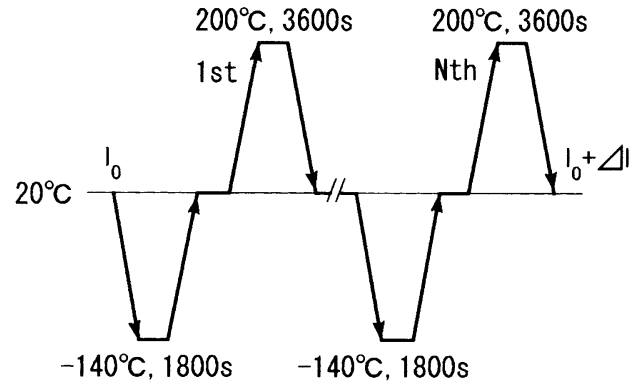

Fig. 2. Accelerated cooling-heating cycle test for measurement of distortion in service.
び $\gamma$ 相の 5つの回折面ピーク， $\alpha(200), \alpha(211), \gamma(200)$, $\gamma(220)$ および $\gamma(311)$ の積分強度から算出した ${ }^{9)}$ 。一方, 残

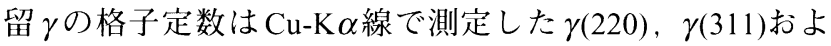
び $\gamma(222)$ 回折ピーク角度から $2 \theta=180^{\circ}$ での值を外挿して求 めた。ただし，炭化物の回折ピークと重なるものについて は, 多重ピーク分離 ${ }^{10)}$ 行った。また，本研究では $\alpha(200), \alpha(211)$ および $\alpha(220)$ 回折ピーク角度から $\alpha^{\prime}$ 母相の 格子定数変化も測定した。

硬さ測定にはロックウェル硬さ試験機（Cスケール）を 用いた。また，微細組織変化は主に透過型電子顕微鏡（加 速電圧 $200 \mathrm{kV}$ ) によって観察した。

\section{3. 実験結果}

\section{$3 \cdot 1$ 微細組織と残留 $\gamma$ 体積率}

焼入れ後サブゼロ処理を施した両鋼の組織の走査電顕写 真を Fig. 3 に示す。 $\mathrm{A}$ 鋼の一次炭化物はB 鋼に比較して均 一であり，また，その炭化物は $\mathrm{M}_{23} \mathrm{C}_{6}$ と少量の $\mathrm{M}_{7} \mathrm{C}_{3}$ から なる（Mは $\mathrm{Fe}, \mathrm{Cr}, \mathrm{Mo}$ を意味する）ことがX線回折， EPMA 分析および電解抽出法により確認できた。写真から 線分法を用いて求めた一次炭化物の体積率および電解抽出 法によって測定した炭化物の質量比はそれぞれ $13 \mathrm{vol} \%$ ， 22.9 mass\%であった。一方，B鋼では 1 次炭化物は $\mathrm{M}_{7} \mathrm{C}_{3}$ の みからなり，その体積率と質量比はそれぞれ $19 \mathrm{vol} \%$ ， 15.0 mass\%であると測定された。

残留 $\gamma$ の体積率は焼入れ状態ではA鋼，B鋼でそれぞれ 約 32 vol\%，16 vol\% であるが，サブゼロ処理によりそれぞ れ約 $10 \mathrm{vol} \% ， 5 \mathrm{vol} \%$ にまで減少する。

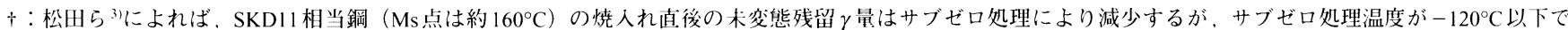

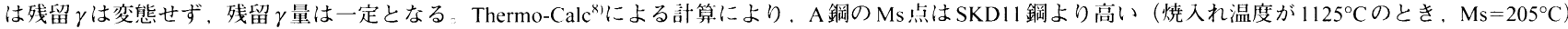
と予想されたので, 本研究では低温側として $-140^{\circ} \mathrm{C}$ を採用した
} 

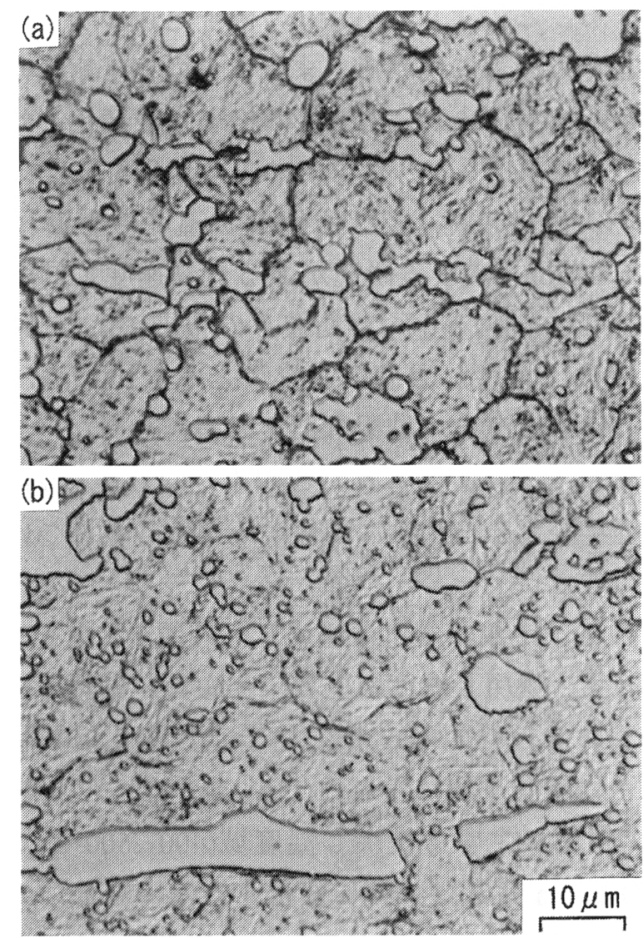

Fig. 3. Scanning electron micrographs of as-quenched steels (a) A and (b) B.

\section{$3 \cdot 2 \mathrm{SZ}$ 材の特性}

Fig. 4aに，SZ材の硬さ(HRC)に及ぼす焼戻し温度の影響 を示す。 $\mathrm{A}$ 鋼はB 鋼に比較して2次硬化が顕著に現れる。 また、 $\mathrm{A}$ 鋼の硬さは焼戻し温度 $500^{\circ} \mathrm{C}$ のとき極大となり,

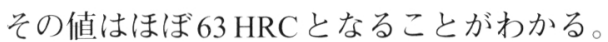

Fig. 5aに，焼入れ，サブゼロ処理，焼戻し処理を順次施 したときの熱処理ひずみ $\left(\varepsilon_{\mathrm{H}}\right)$ の変化を示す。 $\mathrm{A}$ 鋼の試験片 は，焼入れによって収縮後，サブゼロ処理によって膨張し， この後の焼戻しによって収縮するが，その収縮量はFig. $4 \mathrm{~b}$

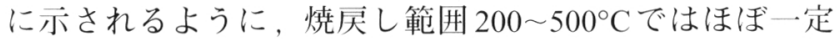
である。一方，B鋼では，このような焼戻し温度域に扑 て収縮量は一定でなく，焼戻し温度が高くなるのに伴い収 縮量は大きくなる傾向が認められる(Fig. 4b)。なお，B鋼 ではA鋼と異なり，焼入れ時に試験片は膨張したが，これ は残留 $\gamma$ 量が相対的に少ないことによる。

Fig. $4 \mathrm{c}$ に経年ひずみ $\left(\varepsilon_{S}\right)$ に及ぼす焼戻し温度の影響を示 す。ただし, 後述する理由から, 繰り返し数は $N=5$ cycles とした。A鋼の経年ひずみはB鋼より全体に小さく, とく に 420 490 $\mathrm{C}$ の焼戻し温度範囲でほぼ 0 となる。このとき, この焼戻し温度範囲では, 残留 $\gamma$ 量 $\left(f_{\gamma}\right)$ の変化は認められ ない(Fig. 4d)。一方, 残留 $\gamma$ が減少する焼戻し温度域では, 経年ひずみが大きくなることが認められる。

いま，許容できる経年ひずみを $1 \times 10^{-5}$ 以下としたとき， これと $62 \mathrm{HRC}$ 以上の高い硬さを両立する焼戻し温度域は $\mathrm{A}$ 鋼では 450 490 ${ }^{\circ} \mathrm{C}$ 範囲にあるが，B鋼では $200^{\circ} \mathrm{C}$ 以下 の焼戻し温度を除き，この条件を満足する焼戻し条件はな いことがわかる。なお， $1 \times 10^{-5}$ 以下の経年ひずみが得ら
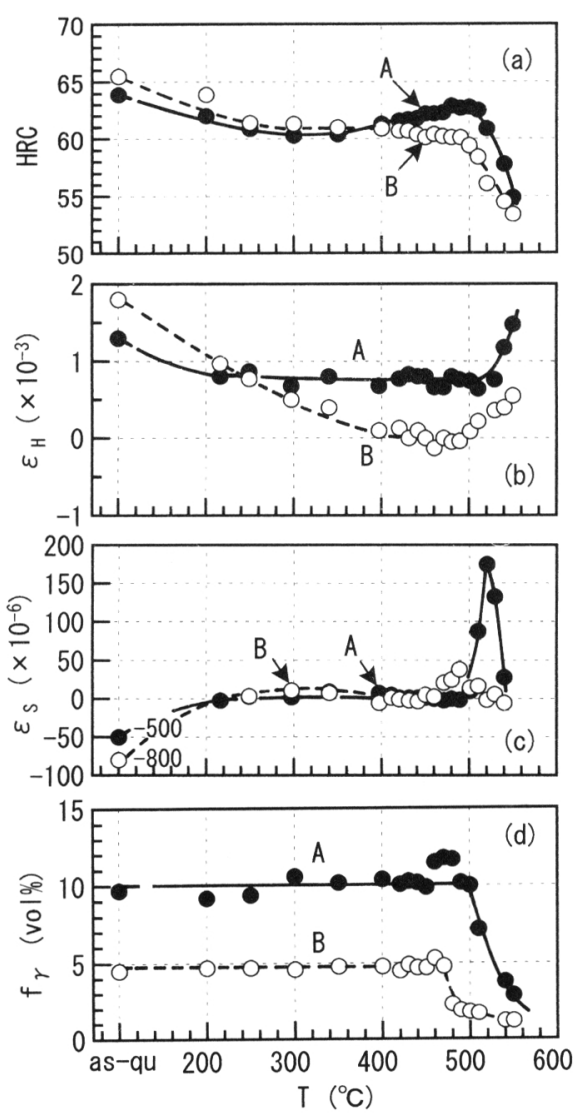

Fig. 4. Variations in (a) hardness (HRC), (b) distortion during heat treatment $\left(\varepsilon_{H}\right)$, (c) distortion in service $\left(\varepsilon_{S}\right)$ and $(\mathrm{d})$ volume fraction of retained austenite $\left(f_{\gamma}\right)$ in SZ specimens of steels A and B.

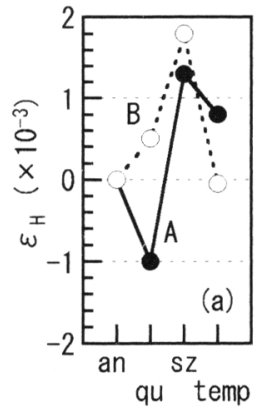

Heat-treat.

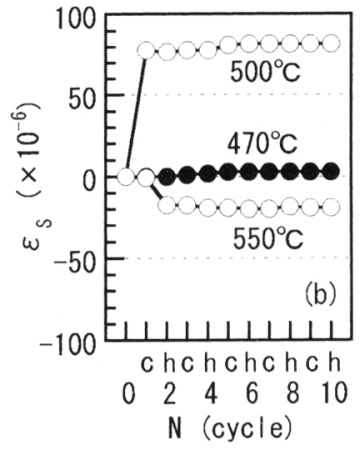

Fig. 5. Variations in (a) distortion during heat treatment $\left(\varepsilon_{H}\right)$ of steels $\mathrm{A}$ and $\mathrm{B}$ and (b) distortion in service $\left(\varepsilon_{S}\right)$ as a function of cycle number for $\mathrm{AQ}$ specimens of steel A tempered at $470^{\circ} \mathrm{C}, 500^{\circ} \mathrm{C}$ or $550^{\circ} \mathrm{C}$. (an: annealing, qu: quenching, sz: subzero treating, temp: tempering at $490^{\circ} \mathrm{C}$ for steel $\mathrm{A}$ or at $470^{\circ} \mathrm{C}$ for steel $\mathrm{B}$, c: cooling, h: heating)

れる焼戻し温度の上限温度は $\mathrm{A}$ 鋼では $490^{\circ} \mathrm{C}, \mathrm{B}$ 鋼では $460^{\circ} \mathrm{C}$ であり, 約 $30^{\circ} \mathrm{C}$ 差がある。

\section{$3 \cdot 3 \mathrm{AQ}$ 材の経年ひずみと残留 $\gamma$ の格子定数変化}

Fig. $5 \mathrm{~b}$ に $\mathrm{A}$ 鋼の $\mathrm{AQ}$ 材の焼戻し材に冷却・加熱サイク 儿試験を施したときの経年ひずみの変化の代表例を示す。 それらの経年ひずみは, 残留 $\gamma$ が存在する場合は 1 サイク ル目の冷却時に大きく膨張し，その後は少し膨張するが 5 

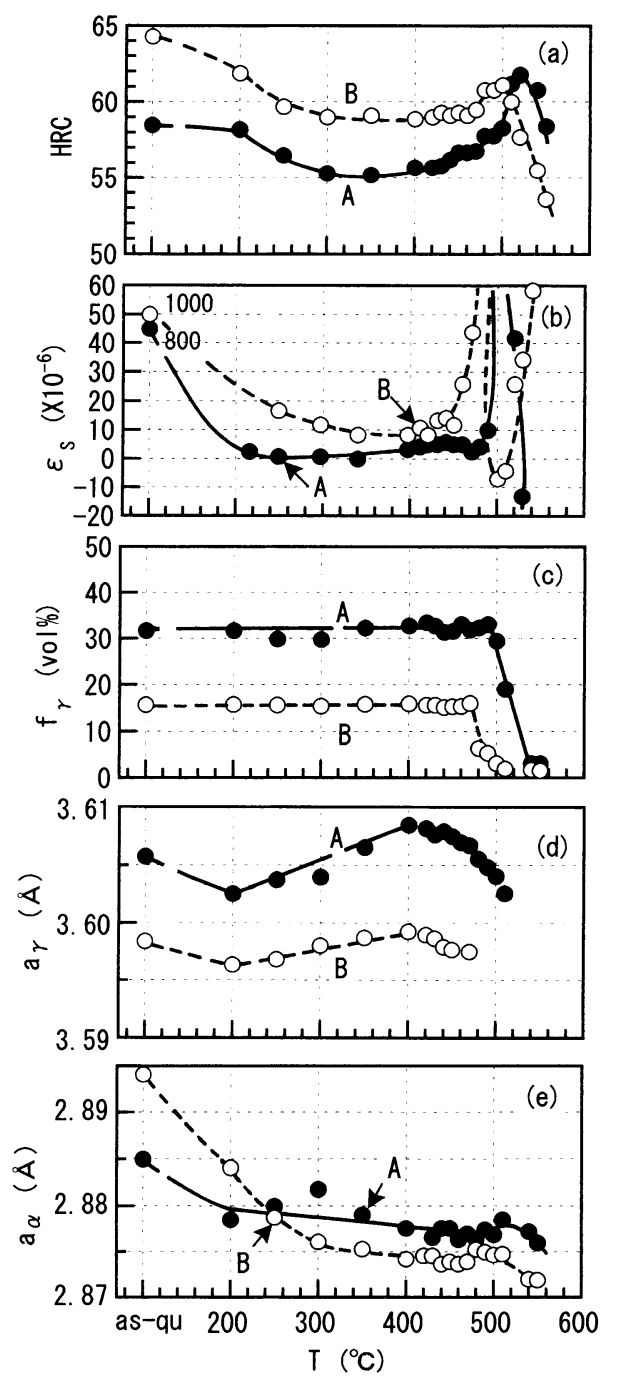

Fig. 6. Variations in (a) hardness (HRC), (b) distortion in service $\left(\varepsilon_{S}\right)$, (c) volume fraction of retained austenite $\left(f_{\gamma}\right)$, (d) lattice constant of retained austenite $\left(a_{\gamma}\right)$ and $(e)$ lattice constant of martensite or ferrite matrix $\left(a_{\alpha}\right)$ for $\mathrm{AQ}$ specimens of steels $\mathrm{A}$ and $\mathrm{B}$.

サイクルでほぼ一定となることがわかる。一方，残留 $\gamma$ の ほとんどが $\alpha^{\prime} に$ 変態する場合 (焼戻し温度 $550^{\circ} \mathrm{C}$ 以上) では，1サイクル目の加熱時に収縮し，その後少し収縮す るものの経年ひずみはほぼ一定となることがわかる。

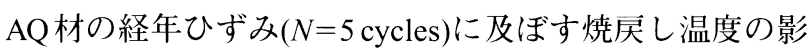
響を Fig. 6bに示す。AQ材の経年ひずみの焼戻し温度依存 性はSZ材とほぼ類似するが, A, B 両鋼の経年ひずみの值 は全体に増加し，かつその焼戻し温度依存性はより顕著に 現れる。

$\mathrm{AQ}$ 材の焼戻し温度にともなう残留 $\gamma$ 体積率および $\alpha^{\prime}$ 相, $\gamma$ 相の格子定数 $a_{\alpha}, a_{\gamma}$ の変化をみると, A鋼では焼戻し温 度が $490^{\circ} \mathrm{C}, \mathrm{B}$ 鋼では $460^{\circ} \mathrm{C}$ 以下では残留 $\gamma$ 量はほぼ一定で 変化しないが(Fig. 6c), 残留 $\gamma$ の格子定数は焼戻し温度に よって大きく変化することがわかる(Fig. 6d)。すなわち， 両鋼とも焼戻し温度が $200^{\circ} \mathrm{C}$ で残留 $\gamma$ の格子定数はいった ん低下し, 最小となった後, $400^{\circ} \mathrm{C}$ ま増加し, その後再
び低下する。このような残留 $\gamma$ の格子定数の変化はA鋼に おいてとくに顕著に現れる。また, その格子定数の值も全 体に高い。参考のため, 残留 $\gamma$ の格子定数変化と対応する $\gamma(311)$ と $\gamma(222)$ ピークプロファイルの変化を Fig. 7に示す。

残留 $\gamma$ の格子定数に及ぼす焼戻し温度の影響について はCohen と Koh ${ }^{11)}$ による研究がある。高速度工具鋼 $(0.7 \mathrm{C}-$ $18 \mathrm{~W}-4 \mathrm{Cr}-1 \mathrm{~V}$, mass\%)を用いた彼らの報告によれば，残留 $\gamma$ の格子定数は焼戻し温度の上昇にともない単調に減少す る。Fig. 6dのような本結果は彼らの報告と異なり, 新しい 知見と考えてよいであろう。このような残留 $\gamma$ の格子定数 変化は経年ひずみと密接に関係するが, これについては考 察で述べる。

$\alpha^{\prime}$ 相の格子定数の変化は必ずしも残留 $\gamma$ の格子定数変化 と対応せず，焼戻し温度の上昇にともない単調に小さくな ること, および $\mathrm{A}$ 鋼の $\alpha^{\prime}$ 相の格子定数変化は $\mathrm{B}$ 鋼に比較 して小さい傾向が認められる(Fig. 6e)。とくに興味深いの

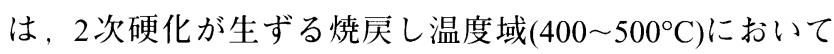
残留 $\gamma$ 相の格子定数は大幅に変化するのに対し， $\alpha^{\prime}$ 相の格 子定数はほぼ一定である点である。参考のため, Fig. 7 に $\alpha(220)$ ピークプロファイルを示す。

\section{$3.4 \mathrm{AQ}$ 材の炭化物析出挙動}

まず，焼入れままおよび $400^{\circ} \mathrm{C}$ 未満の温度域で焼戻しを 施した $\mathrm{A}$ 鋼の $\mathrm{AQ}$ 材において薄膜観察を行ったところ, 焼 入れままの状態で既に $\alpha^{\prime}$ 母相中に多数の $\mathrm{M}_{3} \mathrm{C}$ が存在して いた(Fig. 8)。Inoue と Masumoto ${ }^{12}$ によれば，焼入れまま材 に存在するこれらの $\mathrm{M}_{3} \mathrm{C}$ は焼入れ時の冷却中に過飽和な 炭素によって析出したものと考えることができる。焼戻し 温度が $200^{\circ} \mathrm{C}$ 以下ではその体積率の変化と新たな $\varepsilon$ 炭化物 の析出は認められないが, $200^{\circ} \mathrm{C}$ 以上では $\mathrm{M}_{3} \mathrm{C}$ 体積率が減 少する（再固溶する）ことが観察された。なお，3・1にお いて一次炭化物としては $\mathrm{M}_{7} \mathrm{C}_{3}$ と $\mathrm{M}_{23} \mathrm{C}_{6}$ のみが検出され， $\mathrm{M}_{3} \mathrm{C}$ は検出されなかったが, これは $\mathrm{M}_{3} \mathrm{C}$ 炭化物の体積率 が相対的に低く，かつこれらの炭化物ピークに重なるため と考えられる。

つぎに, 400 490 $\mathrm{C}$ の焼戻し温度域において, 薄膜観察 を行ったところ, $400^{\circ} \mathrm{C}$ 以下で認められた $\mathrm{M}_{3} \mathrm{C}$ 炭化物がす べて消失していた。 $\alpha^{\prime}$ 母相中打よび残留 $\gamma$ 相中に明瞭な 2 次炭化物の析出を確認することはできなかったが，残留 $\gamma$ 相中には2次炭化物の析出の前段階と予想されるひずみ場 が観察された(Fig. 9)。

明瞭な 2 次炭化物の析出は, 残留 $\gamma$ がほとんど分解する $540^{\circ} \mathrm{C}$ 以上の焼戻し温度域で認められ， $\mathrm{A}$ 鋼の $\mathrm{AQ}$ 材では Fig.10に示すような微細な $\mathrm{M}_{23} \mathrm{C}_{6}$ が観察された。この $\mathrm{M}_{23} \mathrm{C}_{6}$ が残留 $\gamma$ と $\alpha^{\prime}$ のどちらの相で析出したかについては 明確な証拠は得られなかった。なお，A 鋼には $2.5 \mathrm{mass} \%$ のMoが添加されているが, EDX分析の結果, 従来の 報告 ${ }^{5,6)}$ と同様に, $\mathrm{Mo}$ の多くは $\mathrm{M}_{23} \mathrm{C}_{6}$ の $\mathrm{M}$ の中に $\mathrm{Fe}$ および Crとともに固溶していた。 


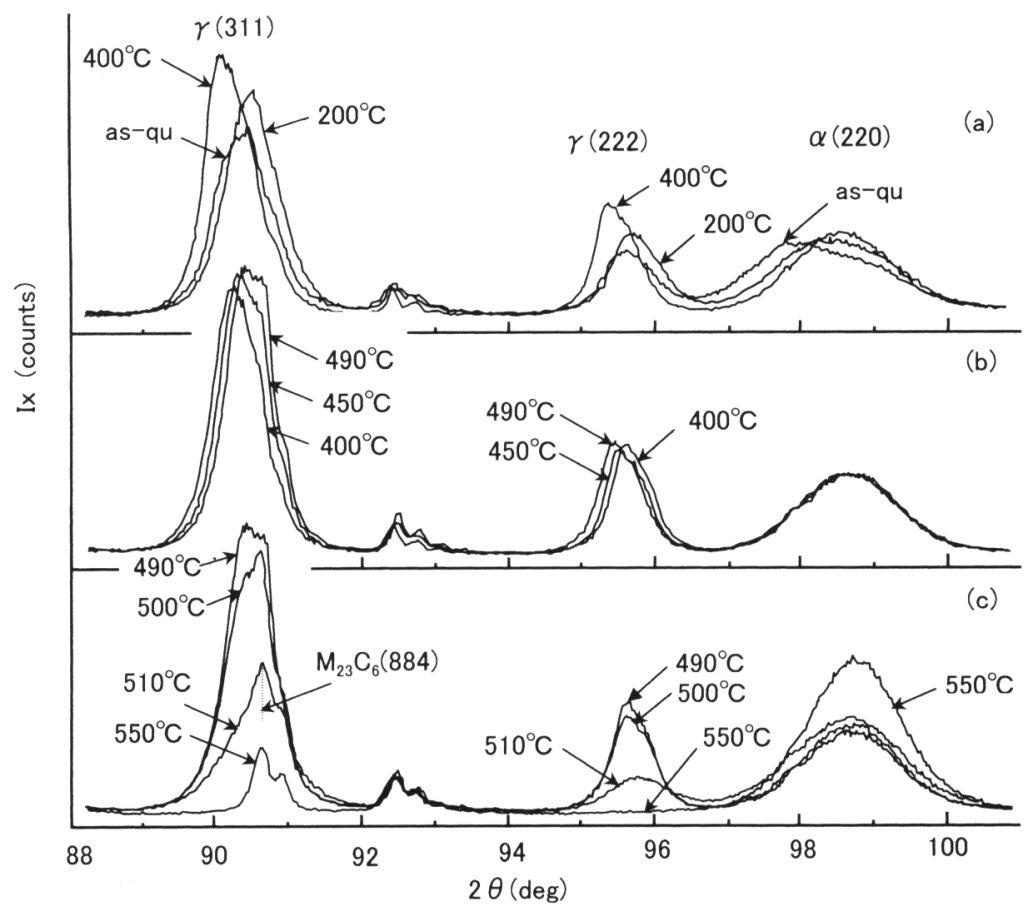

Fig. 7. Changes in $\gamma(311), \mathrm{M}_{23} \mathrm{C}_{6}(884), \gamma(222)$ and $\alpha(220)$ peak profiles with tempering temperature in AQ specimens of steel A.
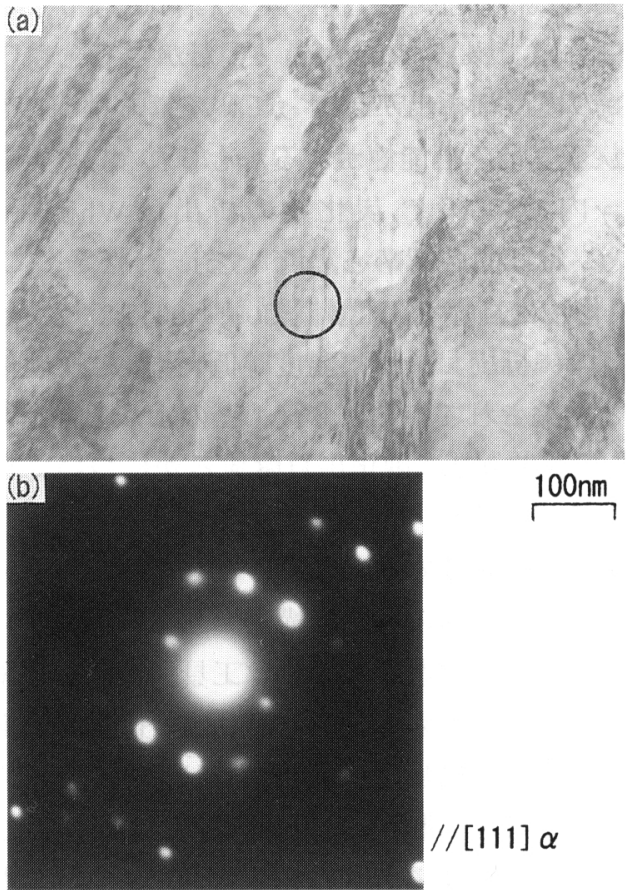

$100 \mathrm{~nm}$

$/ /[111] \alpha$

Fig. 8. Transmission electron micrographs showing $\mathrm{M}_{3} \mathrm{C}$ carbides in martensitic matrix of as-quenched steel A. (a): bright field image and (b): selected area diffraction pattern of encircled area in (a).

$\mathrm{B}$ 鋼の $\mathrm{AQ}$ 材では, 焼戻し温度 $470^{\circ} \mathrm{C}$ において既に $\alpha^{\prime}$ 母 相中に長さ $200 \mathrm{~nm}$ の Widmanstatten 状の $\mathrm{M}_{7} \mathrm{C}_{3}$ 炭化物が観察 される(Fig.11)。この場合, 残留 $\gamma$ 中にはなんらの炭化物も 認められなかった。
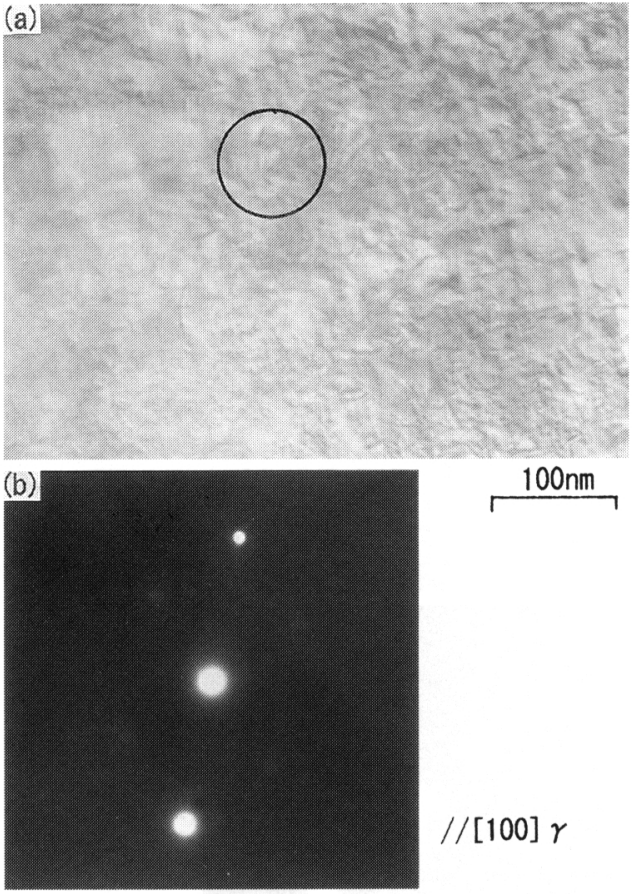

$100 \mathrm{~nm}$

$/ /[100] \gamma$

Fig. 9. Transmission electron micrographs showing microscopic strain fields in retained austenite of $\mathrm{AQ}$ specimen of steel A tempered at $480^{\circ} \mathrm{C}$. (a): bright field image and (b): selected area diffraction pattern of encircled area in (a).

\section{4. 考察}

\section{$4 \cdot 12$ 次硬化機構}

Fig. 6aに示されるように，A鋼ではより顕著な2次硬化 が現れた。 $\mathrm{A}$ 鋼の $\mathrm{AQ}$ 材に扔いて，2次硬化を生ずる焼戻 


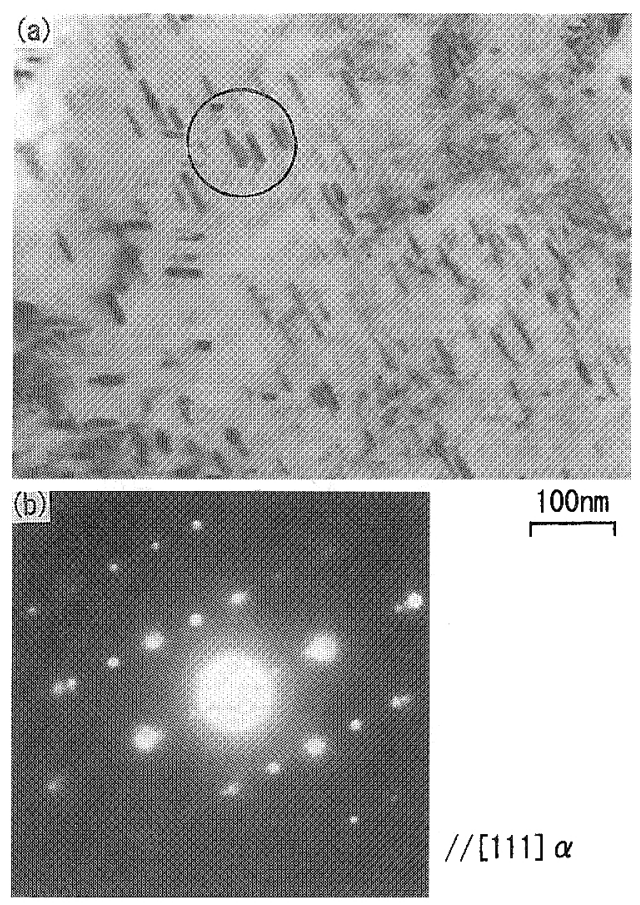

Fig. 10. Transmission electron micrographs showing $\mathrm{M}_{23} \mathrm{C}_{6}$ carbides in $\mathrm{AQ}$ specimen of steel A tempered at $600^{\circ} \mathrm{C}$. (a): bright field image and (b): selected area diffraction pattern of encircled area in (a).
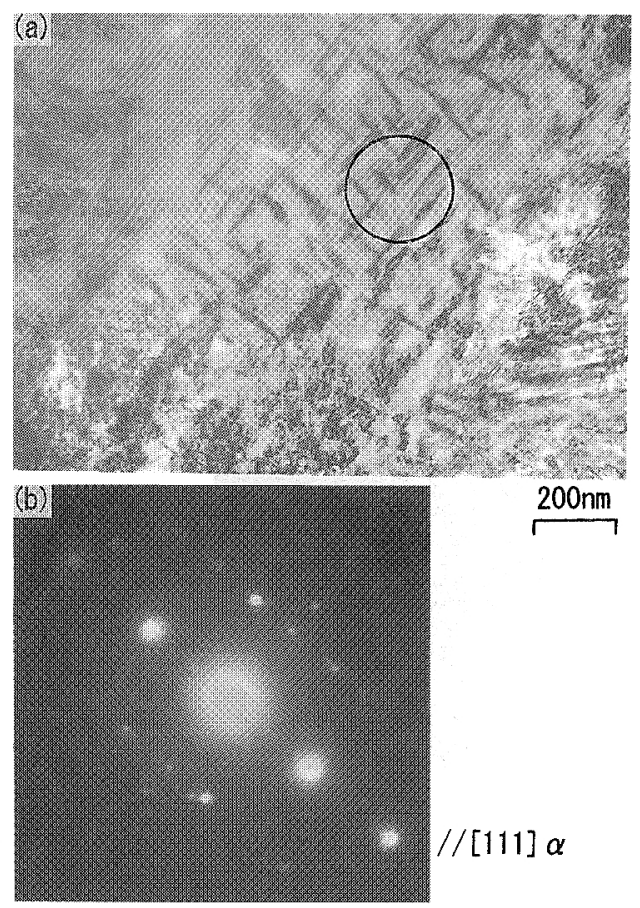

Fig. 11. Transmission electron micrographs showing $\mathrm{M}_{7} \mathrm{C}_{3}$ carbides in martensitic matrix of $\mathrm{AQ}$ specimen of steel $\mathrm{B}$ tempered at $470^{\circ} \mathrm{C}$. (a): bright field image and (b): selected area diffraction pattern of encircled area in (a).

し温度域は残留 $\gamma$ が安定に存在する焼戻し温度域(400 $\left.490^{\circ} \mathrm{C}\right)$ と残留 $\gamma$ の一部または全部が変態または分解する焼 㞍し温度域 $\left(500^{\circ} \mathrm{C}\right.$ 以上) に分けら机る(Fig. 6c)。後者の
焼戻し温度域では，Fig.10に示すような微細 $\mathrm{M}_{23} \mathrm{C}_{6}$ が $\alpha^{\prime}$ 母 相に析出していた。したがって，500 ${ }^{\circ} \mathrm{C} て ゙$ 焼戻しを施した 試験片の顕著な硬さの増加(Fig. 6a)は，冷却中に生ずる残 留 $\gamma$ から $\alpha^{\prime} へ の$ 変態と $\alpha^{\prime}$ 母相内での炭化物析出の両者に 起因していると考えてよいであるう。

一方， $\mathrm{A}$ 鋼の $\mathrm{AQ}$ 材を $400 \sim 490^{\circ} \mathrm{C}$ の温度域で焼戻したと き， $\alpha^{\prime}$ 母相打上び残留 $\gamma$ 相中に2次炭化物の析出の証拠を 得ることはできなかったが，Fig.9に見られるように，残 留 $\gamma$ 相中にひずみ場が観察された。また，Fig. 7b, cに見ら

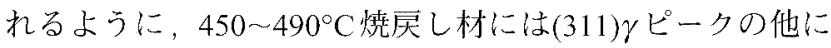
弱い $\mathrm{M}_{23} \mathrm{C}_{6}$ ピークが認められた。したがって，この焼戻し 温度域では, 残留 $\gamma$ 中には解像不可能な極微細な $\mathrm{M}_{23} \mathrm{C}_{6}$ が 析出し，これが2次硬化に役立っていると考えられる。B 鋼の $\mathrm{AQ}$ 材と比較したとき，A鋼はより大きな 2 次硬化を

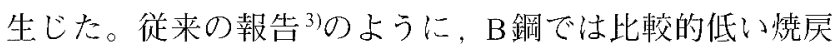
し温度で $M_{7} C_{3}$ が析出し(Fig.11), かつ粗大化するのに対し， $\mathrm{A}$ 鋼では $\mathrm{M}_{23} \mathrm{C}_{6}$ 析出と粗大化が高温焼戻しまで抑制されて いた。これが $\mathrm{A}$ 鋼の大きな2次硬化に貢献していると考兑 られる。

2次硬化に対しては， $\alpha^{\prime}$ 相にも $\mathrm{M}_{23} \mathrm{C}_{6}$ の極微細析出の可 能性があるが， $\alpha^{\prime}$ 母相の格子定数は $400 \sim 490^{\circ} \mathrm{C}$ 贲戻し材 ではほぼ一定であった(Fig. 6e)。したがって，もし $\alpha^{\prime}$ 母相 に $\mathrm{M}_{23} \mathrm{C}_{6}$ の極微細析出が起こっているならば, 残留 $\gamma$ から $\alpha^{\prime}$ への炭素应散の可能性があるかもしれない。

残留 $\gamma$ 内での $\mathrm{M}_{23} \mathrm{C}_{6}$ 炭化物の析出はWhite と Honey-

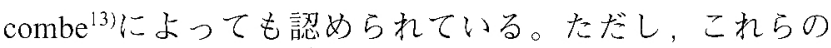
$\mathrm{M}_{23} \mathrm{C}_{6}$ 炭化物は高速度工具鋼索 $300 \sim 400^{\circ} \mathrm{C}$ で焼戻したとき に残留 $\gamma$ 内に析出し，析出温度が低いため2次硬化に貢献 しないと結論されている。今㣪，どのような合金系の場合 に $\mathrm{M}_{23} \mathrm{C}_{6}$ 炭化物が2次硬化に貢献するかについての調査が 必要となるであろう。

\section{$4 \cdot 2$ 小さい経年ひずみ}

\section{$4 \cdot 2 \cdot 1$ 経年ひずみの発生機構}

一般に，工具鋼の経年ひずみは工具鋼の冷却中または工 具鋼に外力が負荷さ机たときに残留 $\gamma$ の化学的安定化状態 が破られ (不安定化し)， $\alpha^{\prime}$ 変態することによって生ずる7)。 これを考慮すると, 焼戻しを施した工具鋼を $180^{\circ} \mathrm{C}$ 近辺で 使用したときに生ずる経年ひずみは次の2つから生ずるひ ずみの和と考えることができる。

(1) 残留 $\gamma$ の一部が $\alpha^{\prime}$ 変態することによって生ずる膨 張 (引張) ひずみ

(2) 上記のフレッシュ $\alpha^{\prime}$ からのと炭化物析出によって 生ずる収縮（圧縮）ひずみ

Fig. $5 \mathrm{~b} よ り$, 残留 $\gamma$ 孝在する場合（焼戻し温度が $530^{\circ} \mathrm{C}$ 以下の場合)，1サイクル目の泠却で試験片の長さは 増加し，その後経年ひずみは少し増加するが，その捘はほ ぼ飽和して一定となる。このように見かけ上，経年ひずみ としては膨張ひずみのみ在生ずるので, (1)の $\alpha^{\prime}$ 変態が主 


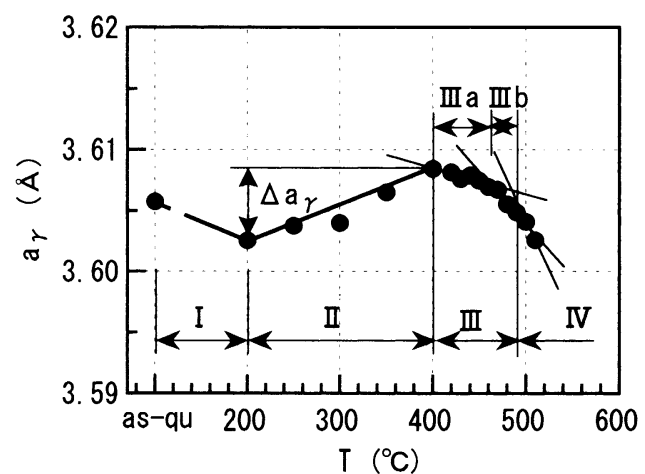

Fig. 12. Typical variation in lattice constant of retained austenite showing four regions I through IV. (steel A)

に経年ひずみの支配因子と考えてよいであろう。 $\alpha^{\prime}$ 変態 量は主に残留 $\gamma$ の安定性と関連するので, 以下では残留 $\gamma$ の安定性, すなわち残留 $\gamma$ の格子定数およびその変化挙動 の結果を用いて経年ひずみを考察する。なお, 焼戻し温度 が $540^{\circ} \mathrm{C}$ 以上の場合に生じた収縮ひずみ(Fig. 5b)は主に上 の(2)に起因したものと考えられる。

\section{$4 \cdot 2 \cdot 2$ 残留 $\gamma$ の格子定数変化}

$\mathrm{AQ}$ 材の残留 $\gamma$ の格子定数変化と炭化物の析出挙動より, 残留 $\gamma$ の格子定数の焼戻し温度依存性は, Fig.12に示すよ うに領域Iから領域IVに分けることができる。領域IIIは 格子定数の減少ぐあいから，さらにIIIaとIIIbの2段階に 分けられる。

一般に, $\gamma$ の格子定数は炭素と堂素の固溶量に大きく影 響され， $\mathrm{Cr}, \mathrm{Mo}, \mathrm{V}$ などの固溶量の影響は小さい(4)。した がって, 上述の残留 $\gamma$ の格子定数変化は固溶炭素濃度変化, つまり炭化物の析出挙動と関連づけて考えてよいであろ う。以下では, とくに重要な領域II と領域IIIの残留 $\gamma$ の格 子定数変化を中心に述べる。

4・1で述べたように，A鋼の $\mathrm{AQ}$ 材を領域 III (400〜 $\left.490^{\circ} \mathrm{C}\right)$ で焼戻しを施したとき, 残留 $\gamma$ 内には $\mathrm{M}_{23} \mathrm{C}_{6}$ の極微 細析出が予想された。これらの炭化物析出は残留 $\gamma$ 中での 固溶炭素の消費を招き，結果として残留 $\gamma$ の格子定数を小 さくしたと考えられる。さきに述べたように，残留 $\gamma$ から $\alpha^{\prime}$ 母相への炭素の拡散が起こり, 極微細の $\mathrm{M}_{23} \mathrm{C}_{6}$ が析出す る可能性があるならば，これも残留 $\gamma$ の格子定数の減少に 寄与すると考えられる。なお，領域IIIbは上述の反応が活 発に起った結果生じたものと予想される。

TEM 観察の結果，領域 IIでは， $\alpha^{\prime}$ 母相中に焼入れ時の 冷却中に生じた長さ 100 200 nmの $\mathrm{M}_{3} \mathrm{C}$ 炭化物が観察され たが(Fig. 8)，焼戻し温度が上昇するにともないその量は減 少し， $400^{\circ} \mathrm{C}$ 焼戻し材には $\mathrm{M}_{3} \mathrm{C}$ 炭化物が全く観察されな かった。したがって，この領域での残留 $\gamma$ の格子定数の増 加は $\alpha^{\prime}$ 母相の $\mathrm{M}_{3} \mathrm{C}$ 炭化物の再溶解に伴う過飽和な炭素が 残留 $\gamma$ へ拡散し，濃化したために起ったものと考えられる。 いま, Fig. $6 \mathrm{~d}$ から求められる $200 \sim 400^{\circ} \mathrm{C}$ の焼戻し温度範

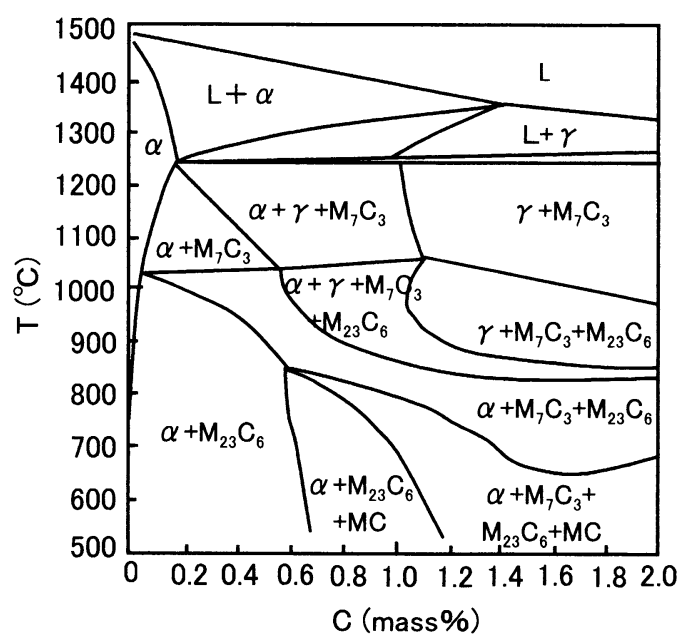

Fig. 13. Equilibrium diagram of $\mathrm{Fe}-(17 \mathrm{Cr}-2.5 \mathrm{Mo}-0.8 \mathrm{~V})$ C system computed by THERMO-CALC.

囲での残留 $\gamma$ の格子定数の増加分 $\Delta a_{\gamma}(\AA)$ （Fig.12参照）を 次式 ${ }^{15}$ に代入して, 領域 II で残留 $\gamma$ 中に濃化される固溶炭 素量 $\Delta C_{\gamma}$ (mass\%)を計算すると，0.136 mass\%と計算され た。

$$
\Delta a_{\gamma}=0.044 \Delta C_{\gamma}
$$

Thermo-Calc ${ }^{8)}$ 用いて作成した $\mathrm{A}$ 鋼の平衡状態図(Fig.13) から, $1125^{\circ} \mathrm{C}$ 加熱時の $\gamma$ 内の炭素濃度は 0.37 mass\%である と計算される。したがって, 領域IIで再固溶し, 残留 $\gamma$ 中 に濃化する炭素濃度は初期濃度に比較して多いと考えてよ い。

\section{$4 \cdot 2 \cdot 3$ 経年ひずみの支配因子}

Fig. $6 \mathrm{~b}$ と $6 \mathrm{~d}$ の比較より, 経年ひずみの小さい $\mathrm{A}$ 鋼は B 鋼に比較して残留 $\gamma の$ 格子定数が全体に大きく，また領域 Iににおける格子定数の増加量 $\Delta a_{\gamma}$ がより大きい特徴をもつ ことがわかる。また, 領域IIIbのように, 残留 $\gamma$ の格子定 数が大きく低下する焼戻し温度域では経年ひずみは大きく なる。これらの事実より，工具鋼の経年ひずみは領域而の 残留 $\gamma$ の格子定数がある限界值以上であれば極めて小さく なること，および残留 $\gamma$ の格子定数が限界值以下となると 経年ひずみは大幅に増加することが予想される。

Fig.14に, C鋼の $\mathrm{AQ}$ 材 $\left(f_{\gamma}=36 \mathrm{vol} \%\right)$ の経年ひずみと残留 $\gamma$ の格子定数の焼戻し温度依存性を示す。C鋼では, 残留 $\gamma$ の格子定数の值が全体に大きいにもかかわらず， $200 \sim 350^{\circ} \mathrm{C}$ 焼戻し温度域での経年ひずみが大きくなってい る。また, 同じ温度域で格子定数の増加量 $\Delta a_{\gamma}$ が極めて小 さいことがわかる。これらの結果は, 経年ひずみの支配因 子として残留 $\gamma$ の格子定数とともに, 領域IIでの $\Delta a_{\gamma}$ 值を 考慮する必要があり, この值がある程度大きいことが経年 ひずみを小さくするのに有効であることを示唆する。この $\Delta a_{\gamma}$ 值の増加は残留 $\gamma$ 中への炭素の固溶量の増加, すなわ ち, 残留 $\gamma$ の安定性の増加を意味するが，その限界值につ 


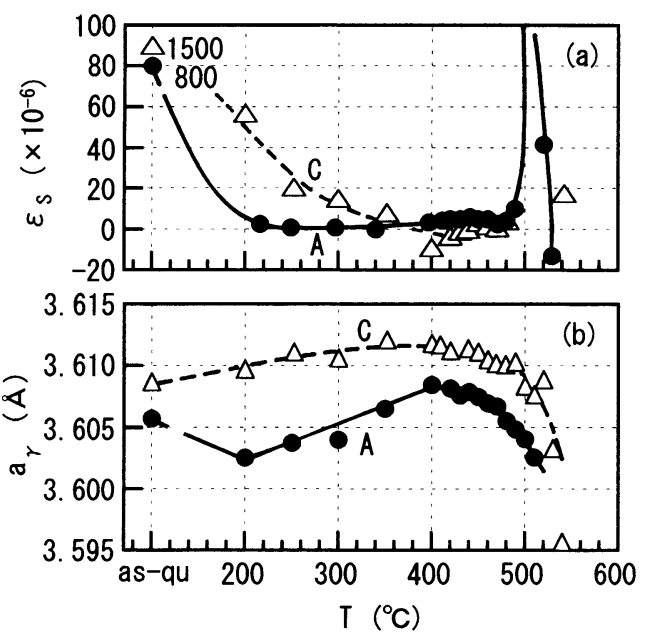

Fig. 14. Variations in (a) distortion in service $\left(\varepsilon_{S}\right)$ and (b) lattice parameter of retained austenite $\left(a_{\gamma}\right)$ as a function of tempering temperature in steel $C$.

いては現在のところ明かでない。

領域IIの低温側において，B鋼の AQ材は比較的大きい 経年ひずみを有した(Fig. 6b)。上述の考え方に従えば，こ れはB鋼の残留 $\gamma$ への炭素の濃化が促進されず，残留 $\gamma$ の 安定性が低いことに起因すると考えられる。Fig. 4bで示さ れたように，B鋼の熱処理ひずみは焼戻し温度が200 $400^{\circ} \mathrm{C}$ の範囲で大きく変化した。炭化物析出に起因すると 考えられるこのような挙動も，B鋼の領域IIの経年ひずみ に関与していると予想される。

最後に，Fig. 5のように，工具鋼の焼入れ，サブゼロ処 理，および焼戻しによって生ずる熱处理ひずみは経年ひず みに比較して極めて大きく $\left(490^{\circ} \mathrm{C} て ゙\right.$ 焼戻したとき， $\mathrm{A}$ 鋼 の最終熱処理ひずみは $\left.0.8 \times 10^{-3}\right)$ ，経年ひずみの発生機構 を考える上で，これらの熱处理ひずみの影響を無視するこ とはできないと予想される。しかしながら，上述の議論か ら，経年ひずみに対して，この熱処理ひずみの影響は残留 $\gamma$ の格子定数拉よびその増加量に比較して小さいと考えら れる。

\section{5. 結言}

（1） $1.2 \mathrm{C}-1 \mathrm{Si}-17 \mathrm{Cr}-2.5 \mathrm{Mo}-0.8 \mathrm{~V}$ 鋼（A 鋼）の SZ材は焼 戻し温度が $490^{\circ} \mathrm{C}$ とき最高の硬さ（62 HRC 以上）と極
めて小さい経年ひずみ $\left(<1 \times 10^{-5}\right)$ を生じた。

（2） $\mathrm{A}$ 鋼の顕著な 2 次硬化に対して，400 490 ${ }^{\circ} \mathrm{C}$ の焼 戻し温度域では主に残留 $\gamma$ 相および $\alpha^{\prime}$ 母相での $\mathrm{M}_{23} \mathrm{C}_{6}$ の極 微細析出が貢献し, $500^{\circ} \mathrm{C}$ 以上の焼戻し温度域では, $\mathrm{M}_{23} \mathrm{C}_{6}$ による析出硬化に加えて焼戻し後の冷却中に生ずる $\alpha^{\prime}$ 変態が寄与することが考えられた。

（3） $\mathrm{A}$ 鋼の残留 $\gamma$ は焼戻し温度が $490^{\circ} \mathrm{C}$ までは変態せ ずに安定であった。また，その残留 $\gamma$ の格子定数はSKD11 相当鋼（B鋼）に比較して高い格子定数を有したが，残留 $\gamma$ の格子定数（安定性）は焼戻し温度にともなって大きく 変化する新知見が得られた。この残留 $\gamma$ の格子定数変化は 焼戻し温度によってI〜IVの4つの領域に分けられた。

（4） $\mathrm{A}$ 鋼の小さな経年ひずみは， $\mathrm{M}_{3} \mathrm{C}$ が再固溶し，か つ $\alpha^{\prime}$ 母相および残留 $\gamma$ 内において特殊炭化物の析出が抑制 されたために，残留 $\gamma$ の格子定数（固溶炭素濃度）が高め られ，結果的に $\alpha^{\prime}$ 変態に対する安定性が増加したことに よって得られたと考えられた。また，経年ひずみは，残留 $\gamma$ の格子定数の值と焼戻し温度域 $200 \sim 400^{\circ} \mathrm{C}$ での残留 $\gamma$ の 格子定数増分の 2 つ主に支配されることが提案された。

本研究の遂行にあたり，日立金属（株）治金研究所の内 田憲正博士には平衡状態図の作成等につきまして数々のご 示唆を頂きました。ここに記して深く感謝致します。

\section{文献}

1 ) T.Yamaguchi: Seikei Kakou, 9 (1997), 350.

2 ) F.Tohyama: The Plastics, 44 (1998), 16.

3 ) Y.Matsuda, K.Sudoh and Y.Hitachi: Denki Seiko, 60 (1989), 311

4 ) Y.Watanabe and M.Nishizawa: unpublished data.

5 ) T.Sato and M.Nishizawa: J. Jpn. Inst. Met., 24 (1959), 473.

6 ) T.Sato, T.Nishizawa and K.Murai: Tetsu-to-Hagané, 44 (1958), 565.

7 ) B.S.Lement, B.L.Averbach and M.Cohen: Trans. Am. Soc. Met., 41 (1949), 1061.

8 ) B.Sundman, B.Jansson and J.O.Andersson: Calphad, 9 (1985), 153.

9 ) H.Maruyama: J. Jpn. Soc. Heat Treat., 17 (1977), 198.

10) X線回折の手引（改定 4 版），理学電気（株）編，東京, (1991).

11) M.Cohen and P.K. Koh: Trans. Am. Soc. Met., 27 (1939), 1015.

12) A.Inoue and T.Masumoto: J. Jpn. Inst. Met., 42 (1978), 787.

13) C.H.White and R.W.K.Honeycombe: J. Iron Steel Inst. Jpn., 197 (1961), 21.

14) 稔野宗次：鉄鋼における変態と析出，日本金属学会編，仙台， (1969), 160

15) B.D.Cullity: Element of X-ray Diffraction, 2nd ed., Addison-Wesley Pub. Co. Inc., Massachusetts, (1978), 508. 